Purdue University Purdue e-Pubs

$12-21-2016$

\title{
Library-Sponsored Case Competitions: Best Practices and Assessment of Learning Gains
}

Ilana Stonebraker

Purdue University, stonebraker@purdue.edu

Follow this and additional works at: http://docs.lib.purdue.edu/lib_fsdocs

Part of the Business Administration, Management, and Operations Commons, and the Information Literacy Commons

\section{Recommended Citation}

Ilana Stonebraker (2016): Library-sponsored case competitions: Best practices and assessment of learning gains, Journal of Business \& Finance Librarianship, DOI: 10.1080/08963568.2016.1258937

This document has been made available through Purdue e-Pubs, a service of the Purdue University Libraries. Please contact epubs@purdue.edu for additional information. 
RUNNING HEAD: LIBRARY-SPONSORED CASE COMPETITIONS: BEST PRACTICES AND ASSESSMENT OF LEARNING GAINS 1

Library-Sponsored Case Competitions: Best Practices and Assessment of Learning Gains

Ilana Stonebraker

Purdue University 


\begin{abstract}
The Parrish Library Case Competition is an annual library-administered, library-sponsored case competition where teams of undergraduate students compete against one another to make better evidence-based decisions for business problems. This article includes a description the case competition as a resource for other libraries interested in sponsoring similar case competitions as part of their information literacy programs. Students who participated in the case competition saw their learning grow as assessed through questionnaires and focus groups. Students who had not taken an information literacy course perceived their understanding as lower than those who had taken a course.
\end{abstract}

Keywords: information literacy, case competitions, undergraduate education, business education 
RUNNING HEAD: LIBRARY-SPONSORED CASE COMPETITIONS: BEST PRACTICES AND ASSESSMENT OF LEARNING GAINS 3

\section{Introduction}

Case competitions are interactive events where participants receive a company scenario (case) for which they need to present a business solution, and are sometimes called the "varsity sport” of business schools (UNC Kenan-Flagler as cited in Sachau \& Naas, 2010). Like many

other types of educational components implemented in both secondary education and higher education, these competitions offer the opportunity to highlight the exceptional work that students do as part of their education. The overall goal of a library-sponsored business competition is different than other case competitions in scope and focus. Like other business competitions, top students show exceptional decision-making and case analysis. The crucial difference in a library-sponsored case competition is that decision-making and case analysis need to be informed by their understanding of the entire ecosystem of discoverable information.

Libraries have hosted paper competitions which award students based on written work in classes. Interactive, live competitions highlight the tangible benefits of information literacy to a larger audience than traditional information literacy in the classroom. In spite of these benefits, libraries have rarely sponsored interactive, live competitions in higher education as of yet. Hosting a live competition expands the library's role from an internal service to a proactive advocate honoring the work of exceptional students inside the classroom to a larger audience of community members, employers, and educators.

The Parrish Library Case Competition highlights how a library-sponsored case competition supplements an existing information literacy program. Competitions benefit undergraduate education, and library-sponsored competitions offer tremendous opportunity both to the library as well as to the student body. Students get an opportunity to translate their information literacy skills into tangible results that can be admired by others. By hosting case 
RUNNING HEAD: LIBRARY-SPONSORED CASE COMPETITIONS: BEST PRACTICES AND ASSESSMENT OF LEARNING GAINS 4

competitions, libraries cultivate information literacy skills and celebrate the skills of exceptional information literate students. This paper will provide a description of a library-sponsored case competition, including the process for administering it and how it scales with other information literacy efforts and programs. Further, this paper will explore assessment of student gains to understand how learning gains may differ between students who had taken an information literacy course before the class and those who had not.

\section{Literature Review}

\section{Case Competitions in Business and Management}

Case competitions stem from teaching using the case analysis method, a common pedagogy used across many disciplines, but most commonly in business schools. In the case method students are given a detailed scenario, or case, for which they need to provide a decision, defended by research and analysis. In traditional case method in the classroom, an instructor walks the students through a discussion of the case (Barnes, Christensen, \& Hansen, 1994). The case competition evolved from the same process but instead of in-class discussions, students independently evaluate the case and then present their solutions.

The format of case competitions varies across disciplines and intent. The time from getting the case until case presentation may be as a short as several hours to as long as a year depending on the learning goals and scope of the case (Sachau \& Naas, 2010). In many case competitions, companies both sponsor the competition and judge the results. In others, a mixture of different business people evaluate the presentations. The contests are very popular and attract many students. In tough job markets, recruiters often posit that participation in case competition gives students in landing jobs and internships. In addition, case competitions are of use to organization who can use case to scout talent (Dunham, 2003). 
RUNNING HEAD: LIBRARY-SPONSORED CASE COMPETITIONS: BEST PRACTICES AND ASSESSMENT OF LEARNING GAINS 5

Case competitions have been shown to benefit students in a variety of ways. Students learn to be effective teammates, apply theory, gain project management skills such as managing heavy workloads, solve organizational problems, and present a persuasive argument to a client (Sachau \& Naas, 2010). Case competitions can be used to enforce concepts using grounded learning (Corner et al., 2006) or experiential learning (Kolb, 2014).

Business librarians are no strangers to case competitions and business plan competitions, and often support information gathering as part of projects. Librarians have been using the case method (Cullen, 2013), case-based method, and problem based methods in the classroom for many years (Carder, Willingham, \& Bibb, 2001). Using cases in information literacy has multiple benefits including matching the pedagogy of the disciplines and making the more theoretical aspects of information searching relevant to the needs of the learner (Spackman \& Camacho, 2009).

\section{Libraries and Undergraduate Competitions}

While arguably libraries and librarians have been participating in competitions from the reference desk for many years, the earliest library-sponsored undergraduate competition was at Hofstra University in 1997 (Hofstra University Library as cited in Tchangalova \& Cossard, 2015). In the Hofstra model, faculty would nominate students or students would self-nominate themselves with an original essay. Starting in 2002, University of California- Berkeley expanded the original Hofstra model with an additional reflective essay on the research experience with the library (Jones, 2009). Over 50 libraries have adopted the UC-Berkeley model (Tchangalova \& Cossard, 2015). These very successful competitions highlight information literacy skills as a part of academia, but lack the team-based case approach of the case competition.

\section{Methods and Design}


RUNNING HEAD: LIBRARY-SPONSORED CASE COMPETITIONS: BEST PRACTICES AND ASSESSMENT OF LEARNING GAINS 6

While case competitions have been implemented for a number of years within business programs, there was no literature currently examining library-sponsored case competitions. What follows is a description of a case competition implemented at Purdue University, a large research university in the Midwest United States. This study includes a successful design of the librarysponsored case competition and its assessed results (surveys and focus groups). It includes a description of how the case came to be sponsored by Parrish Library of Management \& Economics, how a library-sponsored case competition might be different from other case competitions, how resources were located for prizes and how the case was written and judged. Finally, the case is assessed using focus groups and surveys with quantitative analysis. The goal of the study is to build on the existing library literature on how competitions are administered within libraries, but also to show how libraries are unique partners for business schools.

\section{Parrish Library Case Competition Description}

\section{The Impetus}

During the spring of 2014, author of this paper, a business librarian, was teaching an information literacy course and meeting regularly with students about various case competitions. The students had observed that having access to library research, such as market research reports, often gave students a significant advantage in presenting supporting data in these competitions. An undergraduate student suggested that the library, rather than just support case competitions, actually sponsor one. I had been writing cases for problem-based learning for two years in my own classes, so I was familiar with the benefits of having tangible, applicable cases for students to work through.

My hope was to highlight the comparable skills of those who had taken the information literacy course and those who had not in the common currency of the program: case competition 
RUNNING HEAD: LIBRARY-SPONSORED CASE COMPETITIONS: BEST PRACTICES AND ASSESSMENT OF LEARNING GAINS 7

success. I was aware of how important winning a case competition was to the undergraduate students. There were very few case competitions open to freshmen and sophomores. Many students who got involved in case competitions as juniors or seniors started competing too late to build strong case analysis skills before graduation. A library-sponsored case competition offered a low-stakes opportunity for freshmen and sophomores to participate as well as for the library to highlight its freshmen-level information literacy course.

\section{How Library-Sponsored Case Competitions Are Different}

Many other types of business competitions have information literacy aspects, but ultimately, information literacy skills are secondary and in some cases detrimental. Many cases rely on exhibits rather than rely on student's ability to find information. Exhibits are bits of data, such as spreadsheets of financials, pulled market research reports, or descriptions of company locations. The purpose is to focus the students on the information presented versus having them invest time in research. One advantage of exhibits are that they extend the lifespan of the case. However, overachieving students will try to find information on the companies, only to find that they have undertaken a sort of historical reenactment of something that happened years ago. In the space of 2-3 years, a case may lose all relevance to the current state of the real world.

By giving students exhibits, case competitions often deprive students of being able to show the vital business skills of investigating a problem and using information creatively in their solution. Employers have highlighted the importance of research and information as important to informing decision and recommendations, selecting vendors and developing products (Sokoloff, 2012). Case competitions which highlight other soft skills but neglect information gathering run the risk of obscuring important real-world skills. As experts in information literacy, librarians are 
RUNNING HEAD: LIBRARY-SPONSORED CASE COMPETITIONS: BEST PRACTICES AND ASSESSMENT OF LEARNING GAINS 8

ideally suited to design case competitions which highlight those skills and fill a gap in case competition offerings.

\section{The Cases}

In contrast to typical cases for case competitions, a library-sponsored case should be short (1-2 pages) and open to strategic interpretation. The less tied a case is to a specific set of events, the more opportunities for research. Due to this less focused nature, marketing and strategy were the easiest aspect to focus on. They may include real or fictional companies and markets. The first case I used for the case competition focused on entrance into a market (See Appendix B). The second case focused on defense of a market position (See Appendix A). I considered many other options, including marketing plans for specific products or entrepreneurial ideas. I made the choices I did because I wanted there to be enough detail for students to focus but not so much detail that the case is overwhelming. My goal was to introduce students to the idea of the case competitions, and long cases could make later case competitions intimidating. I also wanted to leave as much room as possible for creative use of business information, while still making it clear to undergraduate what was expected of them.

\section{The Logistics}

I relied heavily in the creation of the case competition on my students and the existing case competitions at Purdue. The leadership communication center hosted a yearly case competition. Purdue also participated in national case competitions such as Cummins Case Competitions, CIBER, among others.

For the first year of the competition the library sponsored the prizes, with the prize sponsored in the second year by EBSCO. Prize amounts matched other case competitions at the institution. The first place team won $\$ 500$, the second place team won $\$ 300$, and the third place 
RUNNING HEAD: LIBRARY-SPONSORED CASE COMPETITIONS: BEST PRACTICES AND ASSESSMENT OF LEARNING GAINS 9

team members $\$ 100$, divided among the team members equally. The preferred timeline of the students I consulted was a Wednesday case presentation, with first round presentations and executive summaries due Monday night. These first round presentations were reviewed by the judges, from which the top three were selected and announced. All teams were given feedback and the top three were invited to an in-person final presentation on Friday. In total, the Parrish Case Competition was a nine day long competition.

\section{The Teams}

In the first year, eight teams participated in the case competitions, with sixteen teams participating the second year. In our first year, we extended the competition only to students at Purdue University, but in the second year, we also offered it to Indiana University and University of Notre Dame. Teams were composed of 4-5 members. As the competition was billed as a beginner case competition to get students started, there was emphasis on freshmen and sophomores participating. In the first year at least one freshman or sophomore per team was required and in the second year at least two were required for each team. At least one student on the team had to have taken an information literacy course. This was to ensure that at least one student had been trained on information literacy sources, and could instruct the other students on the team as needed.

\section{The Judging}

The judging panel was a mix of librarians, professors, MBA graduate students and prize sponsors, totaling about five judges in all. In the second year, every institution that participated designated a judge and an organizing librarian. The organizing librarian helped with callouts, answered questions, and did reference interviews with the students. A judging librarian evaluated 
RUNNING HEAD: LIBRARY-SPONSORED CASE COMPETITIONS: BEST PRACTICES AND ASSESSMENT OF LEARNING GAINS 10

the work at the first and final rounds with the other judges. These judging panels were public and the business schools were invited to watch the presentations and the judging.

The judges evaluated the teams using a rubric with many traditional aspects of case competitions judging but with an emphasis on making evidence-based decisions and good use of information in the presentation (see Appendix C). During the final round, teams presented and the judges asked questions. Responses to questions are part of the rubric. Student in general enjoyed the interactions with the judging panel and have asked for more networking time with the judges in the future, especially those from off-campus.

\section{Results}

\section{Assessment Design and Measures}

Assessment on case competitions from the literature mainly focuses either student satisfaction or consulting skills assessment (Sachau \& Naas, 2010). As Sachau \& Naas note, very little quantitative assessment exists for case competitions in the business literature. Assessment of case competition can be helpful to business schools interested in assuring learning of students and the training of staff, especially as it relates to other experiences students have in the curriculum (Credle, Beale, \& Maheshwari, 2009).

The Parrish Library Case Competition was assessed similarly to Sachau \& Naas but with a focus on information literacy skills. Teams filled out surveys about their experiences. Individuals filled out self-assessment questionnaires at the end of the case competition (see Appendix D). Additional focus groups were also held after each case competition, where students were asked what went well and what could be improved for the students that participate in the case competition the next year (see Appendix E). 
RUNNING HEAD: LIBRARY-SPONSORED CASE COMPETITIONS: BEST PRACTICES AND ASSESSMENT OF LEARNING GAINS 11

At Purdue, business librarians teach for-credit courses for information literacy

(Stonebraker, 2015), so I was interested in the inter-relation between our efforts in the

competition and the information literacy classroom. My main assessment questions were:

- Did Parrish Case Competition participants who had not taken an information literacy course learn more from participation in the case competition than Parrish Case Competition participants who had taken the course?

- Beyond the self-assessed learning gains, what positive impacts did the Parrish Case Competition have for the students who did the competition?

\section{Assessed Results}

In questionnaire comments and focus groups, students highlighted three main takeaways from the case competition. First, they appreciated working in a team to creatively find a solution to a problem. Second, they enjoyed looking at marketing and strategy. Third, they enjoyed learning about and from the research databases, using information in their decisions. These benefits were reinforced in the focus groups where students expressed admiration for library databases, embarrassment over not being fast enough when answering judges' questions, and pride in their accomplishments.

Participation in the individual self-assessment was optional and response rate across the two years it was administered was $27 \%(n=29)$. In their individual post-evaluation, students were asked to rank "ability to find useful, accurate, high quality information for academic papers and projects" (information searching) and "use information in business decisions" (information use). They ranked their skill before and after the competition on a Likert scale 1-5. I combined the data from both years and compared the means of students who had taken an information literacy class to those who had not (see Table 1 and 2). Independent sample T-Tests were run for comparisons of means across groups to assess significance.

[Insert Table 1 about here] 
RUNNING HEAD: LIBRARY-SPONSORED CASE COMPETITIONS: BEST PRACTICES AND ASSESSMENT OF LEARNING GAINS 12

[Insert Table 2 about here]

Students who took the survey made statistically significant strides in their self-assessed information literacy knowledge across the information searching and information use ( $p=$ .001). The difference is more prominent in information searching. Students who took an information literacy course assessed their skill as higher $(n=16)$ and built upon that skill in the case competition. Students who had not taken an information literacy course started lower and assessed their information seeking skill as similar to that of the students who had taken the course. Comparing before and after scores from the two groups (those who had taken an information literacy course and those who had not) did not yield statistically significant results, with the exception of a comparison of perceived competence after the case competition $(p=$ $.015)$.

\section{Discussion}

Library-sponsored case competitions should build upon preexisting information literacy experience in the curriculum. This study suggests that students build on their information literacy experiences in the case competition. Student who have taken the information literacy course build upon their skills in the case competition environment. Participation in the Parrish Library Case Competition led to learning gains for both students who had taken an information literacy course and those who had not.

While all groups made self-assessed learning gains, groups performed statistically similar to one another in general. A larger sample size might lead to more significant results. More measures, such as a pre/posttest of information literacy knowledge, would also help us understand better how the Parrish Library Case Competition might be interacting with the curriculum. An objective third party assessment could be needed to counter the Dunning-Kruger 
RUNNING HEAD: LIBRARY-SPONSORED CASE COMPETITIONS: BEST PRACTICES AND ASSESSMENT OF LEARNING GAINS 13

overconfidence effect (Dunning, 2011). Students who have not taken an information literacy course could be overconfident in their abilities. Students overall may be underconfident if they did not make it to the final round of the case competition.

As we look to scaffold experiences, it is vital that case competitions build upon in-class experiences to reinforce concepts at a programmatic level outside of class time. At the same time, competitions will never replace institutionalization. Most case competitions are not required and are episodic in nature and focus. Judging is very subjective and would likely not meet information literacy requirements for accreditation. Student experience is largely reliant on their experience in their self-selected groups. The best use of a case competition is to highlight and encourage information literacy, not as a single one-size-fits-all solution for all students. Libraries should continue to advocate to accrediting bodies, such as Association to Advance Collegiate Schools of Business (AACSB), to include information literacy among required outcomes in undergraduate and graduate programs.

\section{Conclusion}

This paper has provided a description and assessed results of a library-sponsored case competition. It is intended to provide a resource for other librarians who may be interested in hosting similar events at their institutions. Hosting needs for a case competitions are not insurmountable; a small amount of funds for prizes, a space, and judges' time are most important. Increased library-sponsored case competitions allow universities to compete not only in sports and case analysis, but in information literacy as well. Perhaps in the future, exemplary students will travel the country competing against each other in library-sponsored case competitions, inciting information literacy rivalries for years to come. 
RUNNING HEAD: LIBRARY-SPONSORED CASE COMPETITIONS: BEST PRACTICES AND ASSESSMENT OF LEARNING GAINS 14

At Purdue, we plan to continue to offer our undergraduate business competition annually

for the likely future. I am looking at expanding the competition to include the Masters' program. We are also looking at having other library case competitions in the spring and evaluating expanding the case competition to other schools inside Indiana, while still keeping the focus on the Purdue group. We now offer workshops to the case competitions club on campus about the Parrish Case Competition, and have been solicited by professors to do invited lectures on how students can do the types of strategic analysis needed in case competition environments.

The Parrish Library Competition served multiple roles at our university. Firstly, it allowed the library to support students by offering a chance for them to show their information literacy skills to potential employers, faculty, and other students. Secondly, it allowed the library to show how information literacy can be judged with other soft skills in a case competition environment. When librarians consider opportunities for information literacy education, they should consider a diversity of different avenues to showcase information literacy skills and enforce information literacy concepts. This paper suggests how competitive events can be used to showcase those skills and expand the role of information literacy in the business classroom.

\section{Works Cited}

Barnes, L. B., Christensen, C. R., \& Hansen, A. J. (1994). Teaching and the case method: Text, cases, and readings. Harvard Business Press.

Carder, L., Willingham, P., \& Bibb, D. (2001). Case-based, problem-based learning: Information literacy for the real world. Research Strategies, 18(3), 181-190. doi:http://dx.doi.org/10.1016/S0734-3310(02)00087-3

Corner, P. D., Bowden, S., Clark, D., Collins, E., Gibb, J., Kearins, K., \& Pavlovich, K. (2006). 
RUNNING HEAD: LIBRARY-SPONSORED CASE COMPETITIONS: BEST PRACTICES AND ASSESSMENT OF LEARNING GAINS 15

Grounded Learning From a Strategy Case Competition. Journal of Management Education, 30 (3 ), 431-454. doi:10.1177/1052562905277789

Credle, S. H., Beale, R. L., \& Maheshwari, S. (2009). The Use of Case Analysis Training and Competitions to Assure Learning and School-Wide Quality. Business Education \& Accreditation, 1(1), 29-44.

Cullen, A. (2013). Using the case method to introduce information skill development in the MBA curriculum. Journal of Business \& Finance Librarianship, 18(3), 208-232.

Dunham, K. J. (2003). Business-School Contests Give Edge to Job-Hunting Students. Wall Street Journal - Eastern Edition, 241(68), B8. Retrieved from http://search.ebscohost.com/login.aspx?direct=true\&db=buh\&AN=9509481\&site=bsi-live

Dunning, D. (2011). The Dunning-Kruger Effect: On Being Ignorant of One's Own Ignorance. Advances in Experimental Social Psychology, 44, 247.

Jones, L. (2009). The rewards of research Library prizes for undergraduate research. College \& Research Libraries News, 70(6), 338-341.

Kolb, D. A. (2014). Experiential learning: Experience as the source of learning and development. FT press.

Sachau, D. A., \& Naas, P. A. (2010). The consulting challenge: A case competition. Journal of Management Education.

Sokoloff, J. (2012). Information literacy in the workplace: Employer expectations. Journal of Business \& Finance Librarianship, 17(1), 1-17.

Spackman, A., \& Camacho, L. (2009). Rendering information literacy relevant: A case-based pedagogy. The Journal of Academic Librarianship, 35(6), 548-554.

Stonebraker, I. (2015). Flipping the Business Information Literacy Classroom: Redesign, 
RUNNING HEAD: LIBRARY-SPONSORED CASE COMPETITIONS: BEST PRACTICES AND ASSESSMENT OF LEARNING GAINS 16

Implementation, and Assessment of a Case Study. Journal of Business and Finance

Librarianship, 20(4), 283-301. doi:10.1080/08963568.2015.1072893

Tchangalova, N., \& Cossard, P. (2015). Library award for undergraduate research: Increasing the library profile. Practical Academic Librarianship: The International Journal of the SLA Academic Division, 4(2), 1-27.

\section{Appendix A: 2014 Parrish Library Case Competition Case}

Due Tuesday October 21 11:59pm: A slide deck for a twenty minute presentation on the case below. The three best presentations will be announced Wednesday $3 \mathrm{pm}$. Those top three teams will present in person to a panel of judges Friday, Oct 24, starting at 6pm.

John Aguilar is owner of Pets R Us, a (fictional) company specializing in pet food for exotic pets in the United States. Pets R Us is a privately held family business since 1942. It was started originally by John's grandfather, who owned an exotic pet store in Tulsa, Oklahoma. His grandfather didn't see enough quality products for exotic pets and so started selling feed out of his shop. Pets R Us has since become a multi -million dollar company sold in over 37 states and three countries. They distribute their product mostly through specialty pet stores, discounters and mass merchandizers.

Pets R Us currently manufactures and distributes food for birds, rodents and reptiles. Their main office is located in Savannah, Georgia, but they have distributors in Anchorage, Alaska, as well Denver, Colorado. Currently they have a roughly $20 \%$ share in the exotic pets market. Mr. Aguilar has decided to expand his business into new markets as they feel they have saturated the exotic pets market. He has determined that his facilities have the capability of producing additional quantities of pet food product. His factory is certified by the Association of American Feed Control Officials as well as the Food and Drug Administration and he is well versed in the policies of both. Mr. Aguilar is interested in leveraging their market share in the exotic pets market and moving into the mainstream pet food market for dog or cat food. His product has relatively good brand recognition among pet stores and exotic pet owners, but less in the mainstream United States pet market. He is hoping to take advantage of existing trends, building brands that are known to be innovative in the sector.

Their product innovation process is usually this: a new idea is researched or brought to the attention of the marketing department. The marketing department then assesses whether the market is feasible. Pets R Us is generally very effective at keeping costs down, and is confident it 
RUNNING HEAD: LIBRARY-SPONSORED CASE COMPETITIONS: BEST PRACTICES AND ASSESSMENT OF LEARNING GAINS 17

can maintain an efficient supply chain with its ample contacts in the industry. However, moving into the mainstream pet market presents a large amount of risk, as they pride themselves on their product and brand recognition among their niche exotic pet consumers.

How should Pets R Us enter the market? Include a strategic market entry for the company including

- A defined target market (demographics, geography, psychographics)

- A target product (dog or cat food) with rationale

- Trend Analysis

- Technological opportunities

- Processes or models

- Implementation/ Action Plan

- How should they enter the market? What products or marketing tactics should they focus on first? What concrete steps should they take?

Use a combination of library resources and web resources. Your team will be evaluated on the following:

- Definition of the problem and key supplemental issues

- Use of the business information in business decision

- Analysis

- Implementation/Action Plan

- Communication

\section{Appendix B: 2015 Parrish Library Case Competition Case}

Breakfast of Champions? Post Holdings Inc. and the Cold Cereal Market

The overall cereal market is projected to be an $\$ 11$ billion market, with cold cereal making up $87 \%$ of the category. There is significant competition across the different segments of the market with a small number of competitors, primarily, Kellogg's, General Mills, PepsiCo, and Post Holdings, with a fair amount of the market controlled by small companies and private labels. Post Holdings has a $10 \%$ share of cold cereal in the United States. In this market, it has had flat sales $(-0.6 \%)$ during the 52 weeks ending April 18, 2015. While it did experience declines among more healthy brands $-11.1 \%$ for Shredded Wheat and $9.3 \%$ for Grape Nuts - Fruity Pebbles and Cocoa Pebbles brands saw increases of $12.6 \%$ and $6.1 \%$, respectively. At the same time, the success of healthy brands cannot be disputed in the market. Two smaller manufacturers that focused on natural and organic brands have seen some impressive growth over the past year. Nature's Path sales rose from $\$ 70.2$ million to $\$ 77.3$ million during the 52week period, and KIND LLC saw sales of its Healthy Grains granola clusters cereal increase 


\section{RUNNING HEAD: LIBRARY-SPONSORED CASE COMPETITIONS: BEST PRACTICES AND ASSESSMENT OF LEARNING GAINS 18}

from \$23.6 million to \$41.5 million. Consumers' increasing interest in natural products coupled with the desire to support smaller manufacturers is driving this growth. These smaller manufacturers are cutting Post out of the market.

Post has seen several of its major competitors specifically target the nostalgic older consumer and millennial segment. Kellogg introduced Krave, a chocolate cereal targeted at Millennials. General Mills relaunched French Toast Crunch in 2015, which it had removed from its shelves in the 1990s.

Investigate the market for cold cereals in the United States, with specific emphasis on the adult market. Also research Post Holdings, getting to know the many brands which Post owns.

Output: You work in strategic brand management for Post Holdings, Inc. What should Post do to defend their large manufacturing position against smaller brands? Should they embrace a specific adult consumer segment? Your final decision can include any brands within Post's holdings, not just cereal.

Your presentation and executive summary should include

- A defined target market (demographics, geography, psychographics)

- Implementation/Action Plan

- Trend Analysis- What is working? What is failing?

- Processes or models that would help Post understand the market, or suggest innovative solutions

- Explain how evaluated alternatives before reaching your final recommendation

- What products or marketing tactics should they focus on first? What concrete steps should they take?

Powerpoint that includes:

- Labelled Teamname_presentation

- 10-20 slides for a 25 minute presentation

- Can include comments on each slide about what would be said at the point in the presentation

- Should include Works Cited, APA formatted, parenthetical citation on each slides

Executive Summary (1 page) that includes:

- Labelled Teamname_execsummary

- Describe the problem, need or goal

- Describe the proposed solution and the desired outcome

- Explain how evaluated alternatives

- Summarize findings

- Does not need a separated Works Cited, can use parenthetical citation and cite things on the citation slide of the PowerPoint

Use a combination of library resources and web resources.

Your team will be evaluated on the following:

- Definition of the problem and key supplemental issues

- Use of the business information in business decision

- Overall Analysis (trends, process or models)

- Evaluation of alternatives 
RUNNING HEAD: LIBRARY-SPONSORED CASE COMPETITIONS: BEST PRACTICES AND ASSESSMENT OF LEARNING GAINS 19

- Implementation/Action Plan

- Presentation skills and PowerPoint clarity

- Response to questions

Appendix C: Judging Rubric for 2015 Case Competition

Team name:

Evaluator:

\begin{tabular}{|l|l|l|l|l|l|}
\hline & 1 & 2 & 3 & 4 & \\
\hline $\begin{array}{l}\text { Definition of the } \\
\text { problem and key } \\
\text { supplemental issues }\end{array}$ & & & & & \\
\hline Comments: & & & & \\
\hline $\begin{array}{l}\text { Use of the business } \\
\text { information in business } \\
\text { decision }\end{array}$ & & & & & \\
\hline $\begin{array}{l}\text { Comments: } \\
\text { Overall Analysis } \\
\text { (trends, process or } \\
\text { models) }\end{array}$ & & & & & \\
\hline Comments: & & & & & \\
\hline $\begin{array}{l}\text { Evaluation of } \\
\text { alternatives }\end{array}$ & & & & & \\
\hline Comments: & & & & & \\
\hline $\begin{array}{l}\text { Comments: } \\
\text { Plementation/Action }\end{array}$ & & & & & \\
\hline
\end{tabular}


RUNNING HEAD: LIBRARY-SPONSORED CASE COMPETITIONS: BEST PRACTICES AND ASSESSMENT OF LEARNING GAINS 20

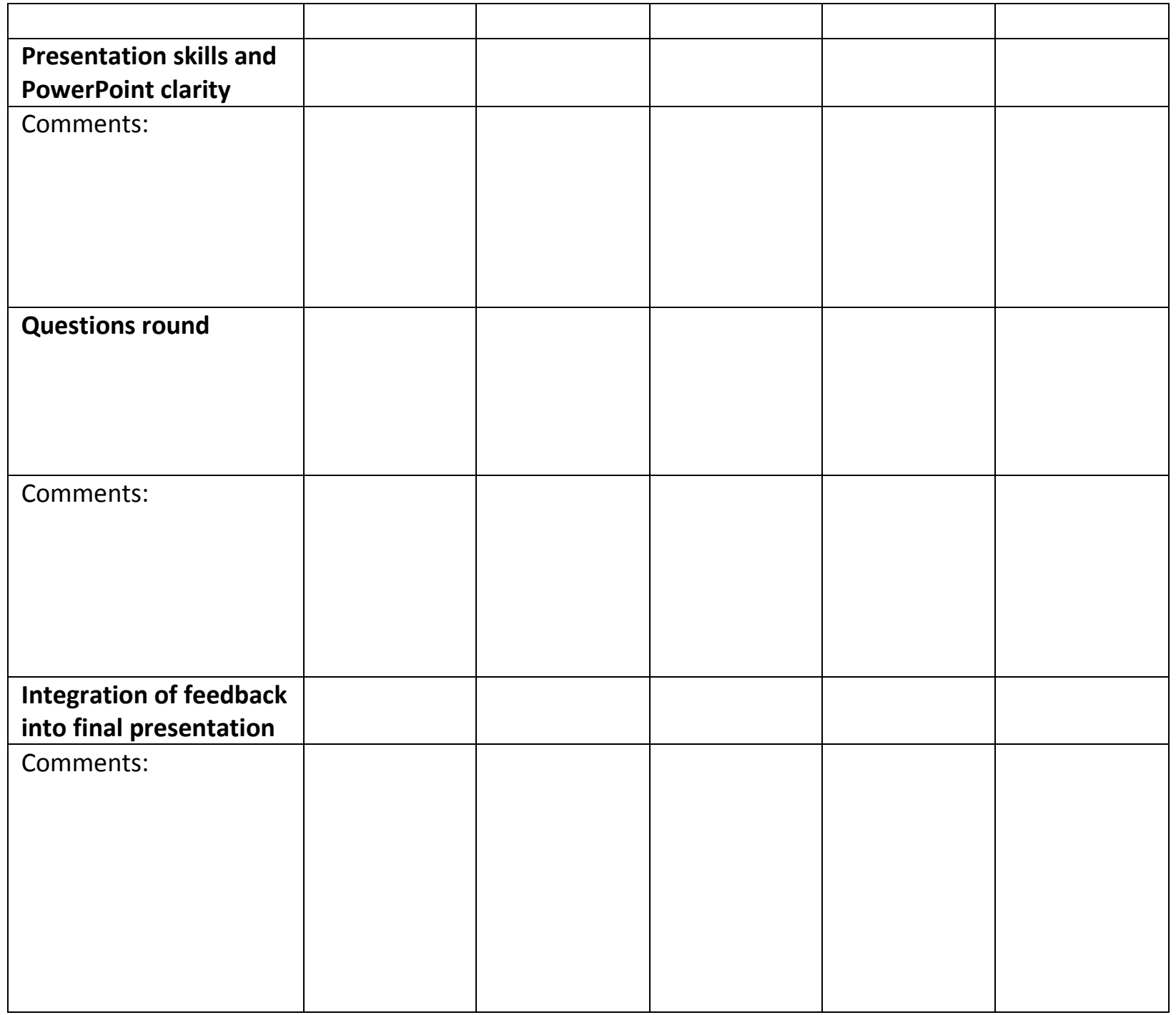

Total:

Additional comments (worth to 10 bonus points) 
Final Total:

Additional comments for team:

\section{Appendix D Student Questionnaire}

Please fill out this survey to the best of your ability. Your individual responses will be kept confidential, though aggregate responses may be used for advertisement for next years' competition. Thank you again for participating in this years' case competition.

Have you taken or are currently enrolled in MGMT 175, MGMT 390 Intro to Management Computing for BOP, or CS104?

Y Yes (1)

No (2)

What is your current year in undergraduate?

Freshmen (1)

Sophomore (2)

Junior (3)

Senior (4)

Other (5)

Please assess your skill before and after participating in the Parrish Library Case Competition. I am confident in my ability to find useful, accurate, high quality information for academic papers and projects.

\begin{tabular}{|c|c|c|c|c|c|}
\hline & $\begin{array}{c}\text { Strongly } \\
\text { Disagree (1) }\end{array}$ & Disagree (2) & $\begin{array}{c}\text { Neither } \\
\text { Agree nor } \\
\text { Disagree (3) }\end{array}$ & Agree (4) & $\begin{array}{c}\text { Strongly } \\
\text { Agree (5) }\end{array}$ \\
\hline $\begin{array}{c}\text { Before Case } \\
\text { Competition } \\
(1)\end{array}$ & 0 & 0 & 0 & 0 & 0 \\
$\begin{array}{c}\text { After Case } \\
\text { Competition } \\
(2)\end{array}$ & 0 & 0 & 0 & 0 & 0 \\
\hline
\end{tabular}


Please assess your skill before and after participating in the Parrish Library Case Competition. I am able to use information in my business decisions.

\begin{tabular}{|c|c|c|c|c|c|}
\hline & $\begin{array}{c}\text { Strongly } \\
\text { Disagree (1) }\end{array}$ & Disagree (2) & $\begin{array}{c}\text { Neither } \\
\text { Agree nor } \\
\text { Disagree (3) }\end{array}$ & Agree (4) & $\begin{array}{c}\text { Strongly } \\
\text { Agree (5) }\end{array}$ \\
\hline $\begin{array}{c}\text { Before Case } \\
\text { Competition } \\
(1)\end{array}$ & 0 & 0 & 0 & 0 & 0 \\
$\begin{array}{c}\text { After Case } \\
\text { Competition } \\
(2)\end{array}$ & 0 & 0 & 0 & 0 & 0 \\
\hline
\end{tabular}

Please assess your skill before and after participating in the Parrish Library Case Competition. I will need to use and evaluate business research in my chosen career.

\begin{tabular}{|c|c|c|c|c|c|}
\hline & $\begin{array}{c}\text { Strongly } \\
\text { Disagree (1) }\end{array}$ & Disagree (2) & $\begin{array}{c}\text { Neither } \\
\text { Agree nor } \\
\text { Disagree (3) }\end{array}$ & Agree (4) & $\begin{array}{c}\text { Strongly } \\
\text { Agree (5) }\end{array}$ \\
\hline $\begin{array}{c}\text { Before Case } \\
\text { Competition } \\
(1)\end{array}$ & 0 & 0 & 0 & 0 & 0 \\
$\begin{array}{c}\text { After Case } \\
\text { Competition } \\
(2)\end{array}$ & 0 & 0 & 0 & 0 & 0 \\
\hline
\end{tabular}

I had fun participating in the Parrish Library Case Competition

Strongly Disagree (1)

$\bigcirc$ Disagree (2)

Neither Agree nor Disagree (3)

O Agree (4)

Strongly Agree (5) 
I learned new things participating in the Parrish Library Case Competition

Strongly Disagree (1)

Disagree (2)

Neither Agree nor Disagree (3)

Agree (4)

Strongly Agree (5)

I enjoyed working with my team in the Parrish Library Case Competition

Strongly Disagree (1)

Disagree (2)

Neither Agree nor Disagree (3)

Agree (4)

Strongly Agree (5)

What was your favorite part of the Parrish Library Case Competition?

What was your LEAST favorite part of the Parrish Library Case Competition?

What would have improved your experience in the Parrish Library Case Competition?

Name (Optional):

Team Name (Optional):

If you would like be informed when the Parrish Library Case Competition is announced next year, please put your email below:

\section{Appendix D Focus Group Questions}

What did you like about the case competition?

How can we get more students involved? How would you guys like to be involved? 
How was the timing of the case competition? Timing of phase 1 and 2 ?

What made you want to do the case competition? Extra credit? Money?

What would have helped you prepare more?

Was the case competition what you expected?

What would have improved the experience?

What other things would you like to include in next year's competition? 